\title{
Penile Cancer cN1 TNM Finding v8
}

National Cancer Institute

\section{Source}

National Cancer Institute. Penile Cancer cN1 TNM Finding v8. NCI Thesaurus. Code C140052.

Penile cancer with palpable mobile unilateral inguinal lymph node. (from AJCC 8th Ed.) 